\title{
Nutrient resorption and adaptation strategy characteristics of two plantations in subtropical China-Ecological stoichiometry
}

Danbo Pang

Li Ma

Genzhu Wang

Miaoying An

Lin Chen

Long Wan

Xiuqin Wu

Jianhua Cao

Jinxing Zhou ( $\nabla$ zjx001@bjfu.edu.cn )

Beijing Forestry University https://orcid.org/0000-0003-2182-9849

\section{Research Article}

Keywords: Ecological stoichiometry, Plantation, Nutrient limitation, Nutrient resorption, Nutrient use strategy

Posted Date: March 30th, 2021

DOl: https://doi.org/10.21203/rs.3.rs-331350/v1

License: (c) (1) This work is licensed under a Creative Commons Attribution 4.0 International License.

Read Full License 


\section{Abstract \\ Background and aims}

Leaf nutrients resorption is critical for considerations of how plants use and recycle nutrients in terrestrial ecosystems. However, information on nutrient resorption and adaptation strategies of the same plant species growing in areas with different geological backgrounds remain poorly understood.

\section{Methods}

We investigated one natural plantation of Pinus yunnanensis Franch. (PY) and one introduced plantation of Eucalyptus maideni F. Muell. (EM) growing under the same climatic conditions but different geological backgrounds (limestone, karst area vs clasolite, non-karst area) in Yunnan Province, China. The C, N, and $\mathrm{P}$ concentrations, nutrient restriction, nutrient resorption efficiency, stoichiometric homeostasis, and plant adaptation strategy indicators were investigated.

\section{Results}

The results showed that soil concentrations of $\mathrm{C}, \mathrm{N}$, and $\mathrm{P}$ were significantly higher in the karst areas compared to the non-karst areas both of the two plantations. Elemental composition of specific plant organs differed significantly between the two sites, while within sites, different organs showed different elemental compositions. In addition, leaf $\mathrm{N}$ : $\mathrm{P}$ ratios and leaf $\mathrm{P}$ resorption efficiencies indicated that plantations in subtropical China are mainly limited by $\mathrm{P}$, which was more evident in the non-karst area. The PY plantation in both areas showed a "conservative consumption" nutrient use strategy, whereas the EM plantation in the two areas showed a "resource spending" nutrient use strategy.

\section{Conclusions}

Plants need to adapt physiologically and morphologically to the harsh conditions in karst areas, resulting in lower growth rates and biomass, more conservative nutrient use, and a high capacity to retain nutrients in the biomass. The findings of this study indicated that trees could synergistically accommodate leaf stoichiometry and nutrient resorption efficiencies in response to different soil types. Overall, our results provide support that the geological background should be considered during the process of vegetation restoration.

\section{Introduction}

Stoichiometry greatly affects ecosystem dynamics and functions due to their association with ecological processes including ecosystem species composition, species diversity, nutrient limitation, and the environmental adaptation of organisms (Wang et al. 2015; Bai et al. 2019). Previous studies shown that 
$\mathrm{C}, \mathrm{N}$, and $\mathrm{P}$ in plants and soil would combine due to their transformation, coordinate, and balance in both subsystems (Kirkby et al. 2011; Agren et al. 2012b; Ostrowska and Porebska 2015). The C, N, and P concentrations and their ratios in the soil serves as a direct indicator of the soil nutrient status, including the plant nutritional status, growth rates, net primary production, and has often been used in study the relationships between above and belowground components of the ecosystem (Wang and Yu 2008; Li et al. 2012; Batjes 2014; Fan et al. 2015; Bai et al. 2019).

The elemental status in different plants varies significantly between different species and within a species across different geographical regions (Wu et al. 2014). In this sense, plant stoichiometry, which is significantly correlated with plant growth and development, has been assessed to explore nutrient limitations and inhomogeneous in various ecosystems (Elser et al. 2010). C, N, and P concentrations differ between various plant organs and geographic areas, and plants are able to regulate stoichiometry in a dynamic and synergetic manner depending on environment (Du et al. 2016). In general, leaf $C, N$, and $P$ concentrations and their ratios are good indicators of soil-plant systems and the content of nutrients in the environment, which can reflect the plants in relation to their $\mathrm{C}$ assimilation and $\mathrm{N}$ and $\mathrm{P}$ absorption (Aerts 1996; Rong et al. 2015). Leaf N: P stoichiometry can be used to predict ecological responses to changes in the environment, as well as the abundance and deficiency of $\mathrm{N}$ or $\mathrm{P}$, which is an important topic in plant functional ecology (Li et al. 2014; Collins et al. 2016). To better understand the plant nutrient status, growth strategies, as well as adaption to terrestrial fragile ecosystems, the pattern of $\mathrm{C}, \mathrm{N}$, and $P$ accumulation and the ratios of these parameters can be used.

Nutrient resorption refers to the transfer of nutrients from senescent leaves to other plant tissues for reuse; this process allowing plants to be less dependent on current soil nutrient availability and improve the plant's nutrient use efficiencies (Leonardus et al. 2012; Sohrt et al. 2018). Therefore, nutrient resorption serves as a key mechanism for plant nutrient conservation, which affects the inter-specific competition, nutrient uptake, productivity, and other critical processes (Yuan and Chen 2009, 2015). Nutrient resorption efficiency (NURE) can be affected by climate factors, species-specific variations, the availability of soil nutrients, and the nutrient concentrations of green leaves, thereby reflecting the limits of nutrient re-use among species adapted to various soil fertility conditions (Tang et al. 2013; Brant and Chen 2015). The effects of the nutrients of green leaves on NuRE are complex, and recent studies used NuRE to explain nutrient limitations. However, nutrient resorption patterns in fragile ecosystems, such as karst, are not well understood.

The karst region in southwest China covers an area of 0.54 million $\mathrm{km}^{2}$, accounting for nearly $12 \%$ of the world's land surface and characterized a highly vulnerable ecosystem (Jiang et al. 2014). Soils are usually thin, coarse, erosive, patchy, with low water retention capacity, and specific regional vegetation characteristics. Due to these features, the karst ecosystem differs from non-karst regions. To restore the ecosystem functions and services, at least to some extent, a number of reforestation projects have been launched in the karst area since the 1990s (Zhu et al. 2012). Our previous researchs have evaluated the effects of afforestation on the soil physicochemical and biological properties of this karst area (Pang et 
al. 2018a,b; Pang et al. 2019). However, information about the growth trees used for environmental restoration in such fragile regions is still scarce.

Karst ecosystems are highly vulnerable to climatic change not only due to the affect soil $\mathrm{C}$ dynamics (Hagedorn et al. 2010), but also because of the impact on ecosystem function. Therefore, studies on the biogeochemical cycling of $\mathrm{C}, \mathrm{N}$, and $\mathrm{P}$ in karst ecosystems may provide important information for the development and optimization of forest restoration programs in fragile environments. Therefore, one natural plantation composed of Pinus yunnanensis Franch. (PY) and one introduced plantation composed of Eucalyptus maideni F. Muell. (EM) were selected in a karst and non-karst areas of southern China to determine the differences in soil and plant ecological stoichiometry, nutrient restriction, NuRE, stoichiometric homeostasis, and plant adaptation strategy. The objectives were to (1) perform a quantitative research on the differences in soil and plant $\mathrm{C}, \mathrm{N}$, and $\mathrm{P}$ concentrations as well as their ratios; (2) provide references for the nutrient restriction and nutrient resorption, as well as different plant growth strategies; and (3) uncover the relationship of $\mathrm{N}$ and $\mathrm{P}$ resorption efficiency with leaf $\mathrm{N}$ and $\mathrm{P}$ concentrations and their ratio. These results provide insight into theoretical stoichiometric characteristics and support ecological restoration and conservation of plantations in fragile karst regions.

\section{Materials And Methods}

\section{Experimental site and sampling area}

This research was conducted at the Xiaoguan Forest Farm, Jianshui County, Yunnan Province, southwest China $\left(104^{\circ} 50^{\prime} \mathrm{E}, 25^{\circ} 40^{\prime} \mathrm{N}\right)$. The distance between the two sites (non-karst and karst) was less than $10 \mathrm{~km}$. Because of the close distance, the two sites had a similar climate, although they had different geological backgrounds. The climate at the two sites is a typical subtropical monsoon climate, the mean annual temperature of approximately $19.8^{\circ} \mathrm{C}$, an annual sunshine duration of $2,322 \mathrm{~h}$, mean annual precipitation of $805 \mathrm{~mm}$, rainfall is concentrated from May to October, and the frost-free period is approximately $307 \mathrm{~d}$ per year. Soils in the non-karst area have developed on clasolite, while soils in the karst area were limestone.

In both sites, the two plantations (PY and EM) were within the scope of the 'Grain to Green' project, meaning that prior to vegetation restoration, both sites were barren mountains. In June 2017, we established twelve sampling plots $(20 \times 20 \mathrm{~m}$, three replicates) in each area; the plots were located more than $50 \mathrm{~m}$ from the forest edge to avoid edge effects. The two areas were similar in terms of vegetation, altitude, slope, and planting pattern. Vegetation surveys in both plantations were conducted in July 2017. The non-karst forests were dominated by trees, with a scattered distribution of shrubs and herbs and large areas of bare soil. The karst forests were dominated by trees and had a large number of shrubs and herbs, covering more than $75 \%$ of the surface. Compared to the karst areas, the two plantations in the non-karst areas were much taller and had a greater diameter at breast height (Fig. 1 and Table 1). Based on the height $(\mathrm{H})$ and diameter at breast height $(\mathrm{DBH}, 130 \mathrm{~cm}) \geq 5 \mathrm{~cm}$ in each plot, the biomass was 
estimated using allometric equations (Chen et al. 2018). The biomass of the two plantations were significantly higher in non-karst areas than in the karst areas (Table 2).

Sample collection and measurements

In each plot, soils were sampled in July 2017 using 4-cm diameter soil cores from a depth of $0-20 \mathrm{~cm}$. The litter layer was removed, the five cores were combined to form one composite soil sample of each plot. Plant samples were collected from twelve dominant trees within each plot. Green leaves were collected in July and senescent leaves were shaken off from branches towards the middle of the trees using a rod (Du et al. 2016); branches, stems, and roots were also collected at the same time. After collection, the plant materials were gently rinsed with deionized water and dried to constant mass $\left(65^{\circ} \mathrm{C}\right.$ for $72 \mathrm{~h}$ ). The plant organs and the air-dried soil samples were ground and sieved through a 60-mesh sieve for analysis. To measure the concentration of soil organic carbon, $0.5 \mathrm{~g}$ soil samples were pretreated with $\mathrm{HCL}\left(10 \mathrm{~mL}, 1 \mathrm{~mol} \mathrm{~L}^{-1}\right)$ for $24 \mathrm{~h}$ to remove carbonate and then analyzed using an elemental analyzer (vario MAX CN, Elementar in Germany) (Mu et al. 2016). Nitrogen (N) concentrations of soil and plant samples were determined after semi-micro Kjeldahl digestion using a flow injection autoanalyzer (Bao 2000). Phosphorus (P) concentrations were analyzed colorimetrically by the ammonium molybdate method (Luo et al. 2013).

Statistical analyses

The stoichiometric ratios of $\mathrm{C}, \mathrm{N}$, and $\mathrm{P}$ in plant organs and soil were calculated based on the mass of $\mathrm{C}$, $\mathrm{N}$, and $\mathrm{P}$. To determine significant differences between the plant organs (green and senescent leaves, branches, stems, and roots) and soils in terms of C, N, P, we used one-way analysis of variance (ANOVA). The effects of different vegetation types and geological backgrounds; different vegetation types and plant organs on $\mathrm{C}, \mathrm{N}, \mathrm{P}$, and stoichiometric ratios were analyzed by two-way ANOVA. The stoichiometric characteristics of soil and plant organs were analyzed via least square difference (LSD) tests, with a significance level of 0.05. All data analyses were performed using SPSS 19.0 (SPSS Inc., Chicago. IL, USA), and figures were generated via Origin 9.0 (Origin Lab., Hampton, MA, USA).

Nutrient resorption efficiency (NuRE, \%) was calculated as the following equation: see equation 1 in the supplementary files.

Where Xgre and Xsen are the nutrient concentrations in green and senesced leaves, respectively, and MLCF is the mass loss modifying factor of 0.745 for conifer, and 0.784 for deciduous (Leonardus et al. 2012).

The homoeostatic coefficient $(H)$ was calculated using the nutrient concentrations of individual leaves from the two plantations and the soil nutrients (Li et al. 2016).

\section{Results}


Soil C, N, and P concentrations and stoichiometry

Soil $\mathrm{C}$ concentrations were higher in the karst area than the non-karst area in both plantations ( $\mathrm{p} \otimes 0.05)$. There was no significant difference between the two plantations in the non-karst area (Fig. 2a). Soil N concentrations have no significant difference between the two plantations both in the karst and non-karst areas (Fig. 2b). Soil P concentrations were higher in the karst area than the non-karst for both plantations ( $\mathrm{\otimes} \otimes 0.05$ ), and there was no significant difference between the two plantations in the non-karst area (Fig. 2c). In general, the three elements concentrations were significantly higher in the karst area than the nonkarst areas for both plantations.

The C: N: P ratios in different vegetation types were significantly different. The soil C: $\mathrm{N}$ and C: $\mathrm{P}$ ratio in the karst area were significantly higher than the non-karst area for the two plantations ( $\mathrm{p} \otimes 0.05)$, whereas there was no significant difference between the two plantations (Fig. 2d,e). The soil N: P ratio in the nonkarst area were significantly higher than the karst area for both plantations ( $\mathrm{p} \otimes 0.05)$, while there was no significant difference between the two tree species growing in different areas (Fig. 2f). The concentrations of soil $\mathrm{C}$ and $\mathrm{P}$ were significantly affected by vegetation types, geological backgrounds and their interaction (Table 3).

$\mathrm{C}, \mathrm{N}$, and $\mathrm{P}$ concentrations and stoichiometry of plant organs

The $\mathrm{C}$ concentrations in leaves, branches, stems, and roots were significantly higher in the karst area than in the non-karst area within the same plantation, except for the stems of EM (Fig. 3a). The N concentrations in roots were significantly higher in the karst area than in the non-karst area within the same plantation (Fig. 3b). The $\mathrm{N}$ concentrations in EM were not significantly different in leaves and stems. The $\mathrm{P}$ concentrations in leaves were not significantly different among the two plantations in the two different areas (Fig. 3c). In general, the $\mathrm{C}, \mathrm{N}$, and $\mathrm{P}$ concentrations differed significantly between plant organs and sites.

The $\mathrm{C}: \mathrm{N}$ ratios in leaves and stems of PY showed opposite trends in the karst and non-karst areas, whereas no significant difference was observed in branches or roots (Fig. 3d). The C: $\mathrm{N}$ ratios in each organ of EM were not significantly different between the karst and non-karst areas. The pattern of C: $\mathrm{P}$ ratios in leaves were not significantly different among the two plantations in the two areas (Fig. 3e). The $\mathrm{N}$ : P ratios in leaves and roots were higher in the karst area than the non-karst area for the two plantations ( $\mathrm{p} \otimes 0.05)$. In contrast, opposite trends were observed in branches and stems from the two plantations (Fig. 3f).

Tree nutrient concentrations and their ratios were significantly affected by vegetation types, plant organs and their interaction $(\mathrm{p}<0.05)$. In the non-karst area, $\mathrm{N}$ concentrations and $\mathrm{C}: \mathrm{N}$ ratios were not significantly affected by their interaction (Table 4). In the karst area, $\mathrm{N}$ concentrations were not significantly affected by vegetation types (Table 4 ).

Nutrient resorption characteristics 
The NRE varied from 30.25 to $50.20 \%$, and the PRE varied from 27.44 to $45.79 \%$ (Fig. 4 a,b). NRE was higher in the karst area than the non-karst area in both plantations ( $\mathrm{\otimes} \otimes 0.05$ ); there was no significant difference between the two plantations in the non-karst and karst areas (pष0.05). PRE was higher in the non-karst area than the karst area of both plantations ( $p \otimes 0.05)$.

The NRE was positively associated with the $\mathrm{N}$ concentrations and $\mathrm{N}$ : $\mathrm{P}$ ratios of green leaves (Fig. 5,6$)$. The PRE was positively associated with the $\mathrm{P}$ concentrations of green leaves (Fig. 7). The PRE was positively associated with the $\mathrm{N}$ : $\mathrm{P}$ ratios of green leaves in the non-karst area of the two plantations (Fig. $8 \mathrm{a}, \mathrm{c})$, whereas it was negatively correlated with the N: P ratios of green leaves in the karst area of PY. No significant relationships were found between PRE and N: P ratios of green leaves in the karst area of EM (Fig. 8 b,d).

Stoichiometric homeostasis characteristics of different tree species

To test the stoichiometric homeostasis, we determined the associations between the leaf $\mathrm{N}$ and $\mathrm{P}$ concentrations, $\mathrm{N}$ : P ratios, and the concentrations and ratios for the soil resources (Table 5). For $\mathrm{N}$ concentrations, leaves of the two plantations in the two areas were $1.341,0.444,0.792,0.961$, respectively, indicating that $P Y$ in the non-karst area showed the highest homeostasis. For $P$ concentrations, leaves from the two plantations in the two areas were $0.770,0.543,0.687$, and 0.587 , respectively. These findings indicate that the same plantation tree species in the non-karst area had higher homeostasis than that in the karst area; PY showed higher homeostasis than EM in the non-karst area. For $\mathrm{N}$ : P ratios, leaves of the two plantations in the two areas were 1.701, 0.813, 0.561, and 1.019, respectively, indicating that PY in non-karst area showed the highest homeostasis. Overall, PY had higher homeostasis in the non-karst area than EM, while in the karst showed the opposite trends.

\section{Discussion}

Differences between soil stoichiometry characteristics of the two stands

Soil C, N, and P are influenced by climates, vegetation types, soil substrates, and parent materials (Zhou et al. 2016; Wang et al. 2018; Qiu et al. 2020). The karst area showed significantly higher C, N, and P concentrations than the non-karst area for both plantations. The reasons for these differences are unclear; however, we offer three different explanations: First, soil C, N, and P concentrations in the two field sites were associated with vegetation growth; in the non-karst area, which had minimal understory vegetation and large parts of the soil surface exposed, this resulted in high nutrient leaching and soil erosion (Liu et al. 2016; Orefice et al. 2017). Second, due to the OM-Ca ${ }^{2+}$-mineral complex in soils rich in $\mathrm{Ca}$, higher exchangeable $\mathrm{Ca}$ concentrations result in greater soil $\mathrm{C}$ and $\mathrm{N}$ pools in the karst area ( $\mathrm{Li}$ et al. 2017). Third, with a high understory vegetation coverage in the karst area, plant litter and organic matter inputs increase, facilitating microbial decomposition processes and resulting in nutrient accumulation (Pan et al. 2015; Mclntosh et al. 2016). In our study, we also observed that soil C, N, and P concentrations 
were significantly lower in the PY plantation than the EM plantation in both the areas, which may result from the acidity of the foliage and litter of coniferous trees (Cao et al. 2018).

Soil C: N: P ratio is an important indicator of soil quality. It also reflects the variability of ecosystem functions and nutrient cycles (Cao and Chen 2017). In general, the lower C: $\mathrm{N}$ ratio indicates $\mathrm{N}$ mineralization dominant (Bui and Henderson 2013; Zhao et al. 2015). In this study, all the treatments had lower soil C: $\mathrm{N}$ ratios (Fig.2d), indicating that the subtropical forests had a higher nitrogen mineralization rate. As soil P in the non-karst area was obviously lower than the karst area, soil N: P ratios in the nonkarst area was significantly greater compared with the karst area. This is most likely a result of higher precipitation and soil moisture in the study areas, which led to increased soil weathering and a more rapid release of P from karst areas than non-karst areas (Houlton et al. 2008; Yang et al. 2018).

Differences between plant C: N: P stoichiometry of the two stands

Previous studies have shown that the nutrient concentrations differed between different plant organs, probably as a result of varying genetic expression (Han et al. 2005). In this study, C, N, and P concentrations differed between plant organs and study sites. The concentrations of $\mathrm{C}$ in the organs of each tree species in the karst and non-karst areas were not significantly different (Fig. 3a). This because C provides the structural basis and plant skeleton (Zhang et al. 2019; Qiu et al. 2020). Our research also showed that the $\mathrm{C}$ concentrations in PY were higher than that in EM in all the plant organs, which in line with previous studies. Overall, these findings suggests that conifers are rich in C compounds compared to primary and secondary forests and broad-leaved plantations (Yuan and Chen 2009; Fan et al. 2015). Plants growing in subtropical areas under high temperatures, strong sunlight, and heavy precipitation exhibit a high capacity for cell division and therefore require large amounts of protein, such as Rubisco, for photosynthesis and plant growth. The large amounts of Rubisco, the pivotal enzyme of the Calvin cycle, may explain the relatively high $\mathrm{N}$ concentrations in leaves compared to other plant organs (Gorokhova and Kyle 2002; Reich and Oleksyn 2004; Bloomfield et al. 2014). The P forms in leaves have been shown to be relatively variable, as plants can store not only organic $P$, but also inorganic $P$ in leaves (Agren and Weih 2012a; Mayor et al. 2014). In our study, leaf P concentrations were found to be higher than the average leaf $P$ concentrations in terrestrial ecosystems (Elser et al. 2008). One explanation for this might be that plants under high soil $P$ conditions store higher concentrations of inorganic $P$ in the cytoplasm and vacuoles of leaves (Mayor et al. 2014). Previous studies showed that high $\mathrm{N}$ or $\mathrm{P}$ concentrations correspond to faster growth rates and stronger competitive ability for resources (Shipley et al. 2006; Huang et al. 2019).

Leaf stoichiometry is an important parameter for studying the nutrient restriction, cycling, and response of plants to the climate change. We found that the $\mathrm{C}$ : $\mathrm{N}$ ratio in leaves ranged from 9.81 to 15.12 with an average of 12.54, and the $\mathrm{C}$ : $\mathrm{N}$ ratio in other plant organs ranged from 12.20 to 28.52 with an average of 19.94 , indicating that the $\mathrm{N}$ concentration in leaves was lower than that of other organs. These findings are inconsistent with previous study conducted in subtropical China (Luo et al. 2020). This might be explained by the fact that element concentrations can be maintained at relatively stable concentrations to 
adapt to environmental changes (Jeyasingh et al. 2009). Differences in photosynthetic capacity, plant morphology, and adaptation strategies might explain why the same elements and stoichiometry of plant organs differed between the two field sites.

Leaf $\mathrm{N}$ and $\mathrm{P}$ concentrations and nutrient restriction

Generally, leaf $\mathrm{C}, \mathrm{N}$, and $\mathrm{P}$ concentrations and N: P ratios are good indicators of the plant-soil interactions and the nutrient content of the environment (Aerts 1996). $\mathrm{N}$ and $\mathrm{P}$ have a close relationship to the production of proteins, amino acids, and nucleic acids as well as the biosynthesis associated with plant issues (Zhang et al. 2012; Pan et al. 2015). The leaf N: P ratio greatly reflects nutrient limitations in plants, affecting plant traits, community composition, and biodiversity. N: $\mathrm{P}$ ratio of less than 14 indicates $\mathrm{N}$ limitation, whereas a ratio over 16 reflects $\mathrm{P}$ limitation, while ratio from 14 to 16 suggests $\mathrm{N}$ and $\mathrm{P}$ colimitation during plant growth and development (Koerselman and Meuleman 1996). In this study, the leaf $\mathrm{N}$ : $\mathrm{P}$ ranged from 17.12-26.62, and the average leaf $\mathrm{N}$ : $\mathrm{P}$ across all treatments was 20.01; therefore, under our experimental conditions the growth of the trees was limited by $\mathrm{P}$. The average leaf $\mathrm{N}$ : $\mathrm{P}$ in PY of both areas was 22.17, while the average leaf $\mathrm{N}$ : $\mathrm{P}$ in EM was 17.85 in both areas, indicating that the growth of PY was more limited by $P$ than EM. Which consistent with the "growth rate hypothesis" that faster growing plants would have lower leaf $\mathrm{N}$ : $\mathrm{P}$ ratios due to a high requirement of P-rich ribosomal RNA relative to N-rich proteins.

Differences in plant species and diversity result in different nutrient use efficiencies and competition for nutrients (Bing et al. 2016). With the climate fluctuations and greater extremes of climate change, it is essential to understand how plants that are dominant in a fragile ecosystem respond to stoichiometric changes. Previous studies have indicated that plants that exhibit higher growth potential require more nutrients to ensure biomass production; therefore, the must have a higher NuRE (Pan et al. 2015; Sun et al. 2016). The averages of NRE and PRE in the two plantations were $39.91 \%$ and $34.61 \%$, respectively (Fig. 4 a,b), which were lower than those in global terrestrial forests ( $47.4 \%$ to $62.1 \%$ and $53.6 \%$ to $64.9 \%$, respectively) (Vergutz et al. 2012; You et al. 2018). The unexpectedly low NuRE may be explained by the high variation nutrient use strategies in subtropical forests. In our research, the NRE in the karst area was greater than that in the non-karst area for both plantations. These findings indicate higher $\mathrm{N}$ deficiencies in the karst area; PY had higher $\mathrm{N}$ deficiencies than the EM in both study sites. Our research also showed that NRE was positively correlated with the $N$ concentrations and $N$ : $P$ ratios of green leaves $($ Fig. 5,6$)$. The PRE in the karst area was lower compared with the non-karst area for both plantations. Overall, the plantations had higher $\mathrm{P}$ deficiencies in the non-karst area, and $\mathrm{PY}$ had higher $\mathrm{P}$ deficiencies than EM in both field sites (Fig. 4b). The higher PRE might be a strategy for adapting to the P deficient soils of plantations in subtropical China, which is in agreement with the findings of previous studies (Qiu et al. 2020; Tong et al. 2020). The PRE was positively correlated with the P concentrations of green leaves (Fig. 7), which is also consistent with previous studies (Zhou et al. 2016; Zhang et al. 2018). The higher PRE than NRE in the non-karst area suggested that the plantations were generally limited by $P$ availability, supporting the "relative resorption hypothesis" that plants would have higher NuRE when growing under 
$\mathrm{N}$ or $\mathrm{P}$ limitation (Gusewell 2005). Thus, we assume that the high $\mathrm{N}$ and $\mathrm{P}$ resorption rate contribute to the moderation of the $\mathrm{N}$ and $\mathrm{P}$ deficiencies in the two areas.

\section{Element resorption as an adaptive strategy to nutrient limitation}

NuRE serves as a significant indicator of plants to sustain adequate nutrition concentrations, thereby affecting plant growth, nutrient uptake, inter-specific competition, biomass production, and net productivity (Killingbeck 1996; Liu et al. 2016). Previous studies have shown that tree species from infertile soils usually have low leaf nutrient concentrations and higher NuRE values; thus, they will adopt a "conservative consumption" nutrient use strategy to ensure their survival and reproduction (Kobe et al. 2005; Yan et al. 2006). In contrast, tree species from nutrient-rich locations usually adopting a "resource spending" nutrient use strategy to grow (Wright and Cannon 2001; Zeng et al. 2017). In our research, the lower concentrations of nutrients in soil and leaves coupled with the high NRE and PRE (Fig. 2,3,4) indicate that PY in the two areas adopted a "conservative consumption" nutrient use strategy, EM in both areas adopted a "resource spending" nutrient use strategy.

In our study, both tree species in the karst area showed an increased NRE compared to the same tree species in the non-karst area; hence, it is expected that plants in karst areas would require less $\mathrm{N}$ from the soil for new growth. In our research, the PRE in the karst area was lower than that in the non-karst area for both plantations. High $\mathrm{P}$ resorption rates may contribute to the moderation of $\mathrm{P}$ deficiency in the nonkarst area. The reasons for this are still unclear; however, we propose that in the karst area, relatively high soil $\mathrm{pH}$ together with rich $\mathrm{CaCO}_{3}$ make the total $\mathrm{Ca}^{2+}$ content high in soil, which leads to a large exchangeable calcium reservoir, forming an insoluble Ca-P phase. As a result, the $\mathrm{CaCO}_{3} / \mathrm{AP}$ (available phosphorus) ratio increases and plant-available phosphorus decreases in soil (Carreira et al. 2006; Ma et al. 2009; Zhao et al. 2012; Hong et al. 2014). In non-karst areas, plants possessing a relatively high growth rate need high $\mathrm{P}$ allocation rates and high metabolic rates to meet their high energy demands for the synthesis of macromolecules (Vitousek et al. 2010; Sun et al. 2016). However, some authors have suggested that higher NuRE does not serve as a significant mechanism for plants to adapt to low-fertility habitats and that phylogenetic and genetic difference take effect (Yan et al. 2008).

The PRE was lower in the karst area compared with the non-karst area, whereas NRE showed the opposite behavior. Overall, poor growth was observed for the two tree species in the karst area (Fig. 1), which has also been observed for Arabidopsis thaliana (Yan et al. 2015). In karst areas, trees must physiologically and morphologically adapt to the harsh conditions. As a result, the growth rate decreases and the use of nutrients becomes more conservative, which might contribute to a competitive edge for plants (Du et al. 2011; Wang et al. 2015). The difference in stoichiometric homeostasis $(H)$ may reflect the trade-off of nutrient investment strategy in plants (Yu et al. 2011). The $H_{N}, H_{\mathrm{P}}$, and $H_{\mathrm{N}: \mathrm{P}}$ among different trees species varied in our research, suggesting that different trees exhibited different adaptation strategies. The results of our study led us to infer that in fragile ecosystems, the reuse of $\mathrm{N}$ and $\mathrm{P}$ from the senescent leaves might serve as a special nutrient preservation strategy to improve plant growth, and NuRE in trees are flexible and can be adapted to different environments. 


\section{Conclusions}

Our study showed that soil C, N, and P concentrations were significantly higher in the karst area than in the non-karst area. Both tree species had lower soil C: $\mathrm{N}$ ratios, indicating that subtropical forests had a greater nitrogen mineralization rate. Plant stoichiometry and stoichiometric homeostasis were different between the two plantations within different sites. In addition, the N: P ratio and PRE showed that both sites were $\mathrm{P}$ deficient, and the growth of $\mathrm{PY}$ was more limited by $\mathrm{P}$ than $\mathrm{EM}$. Furthermore, dominant tree species in subtropical areas adopted different nutrient use and adaptation strategies. Under the different geological backgrounds, vegetation restoration leads to great differences in plant parameters such as physiological, morphological, element concentrations, and adaptation strategies. Our findings provide a scientific basis for the development and optimization of restoration projects in harsh, fragile ecosystems.

\section{Declarations}

\section{Acknowledgements}

This study was supported by the National Natural Science Foundation of China (31870707, 31700640), the Natural Science Foundation of Ningxia Hui Autonomous Region (2020AAC03102), and the National Key R\&D Program of China (2016YFC0502504). We also appreciate the editor and the reviewers for giving us constructive suggestions.

\section{References}

Aerts R (1996) Nutrient resorption from senescing leaves of perennials: are there general patterns? Journal of Ecology 84: 597-608.

Agren GI (2004) The C: N: P stoichiometry of autotrophs-theory and observations. Ecol Lett 7: 185-191.

Agren GI, Weih M (2012a) Plant stoichiometry at different scales: element concentration patterns reflect environment more than genotype. New Phytol 194: 944-952.

Agren GI, Wetterstedt JAM, Billberger MFK (2012b) Nutrient limitation on terrestrial plant growthmodeling the interaction between nitrogen and phosphorus. New Phytol 194: 53-960.

Bai XJ, Wang BR, An SS, Zeng QC, Zhang HX (2019) Response of forest species to C: N: P in the plantlitter-soil system and stoichiometric homeostasis of plant tissues during afforestation on the Loess Plateau, China. Catena 183:104186.

Bao SD (2000) Soil and agricultural chemistry analysis, The 3rd edition. China Agriculture Press, Beijing. Batjes N (2014) Total carbon and nitrogen in the soils of the world. Eur J Soil Sci 65: 10-21. 
Bing HJ, Wu YH, Zhou J, Sun HY, Luo J, Wang JP, Yu D (2016) Stoichiometric variation of carbon, nitrogen, and phosphorus in soils and its implication for nutrient limitation in alpine ecosystem of Eastern Tibetan Plateau. Journal of soils and sediments 16: 405-416.

Bloomfield KJ, Farquhar GD, Lloyd J (2014) Photosynthesis-nitrogen relationships in tropical forest tree species as affected by soil phosphorus availability: a controlled environment study. Funct Plant Biol 41: 820-832.

Brant AN, Chen HY (2015) Patterns and mechanisms of nutrient resorption in plants. Crit Rev Plant Sci 34: $471-486$.

Bui EN, Henderson BL (2013) C: N: P stoichiometry in Australian soils with respect to vegetation and environmental factors. Plant and Soil 373: 553-568.

Cao Y, Zhang P, Chen YM (2018) Soil C: N: P stoichiometry in plantations of N-fixing black locust and indigenous pine, and secondary oak forests in Northwest China. Journal of Soils and Sediments18: 1478-1489.

Cao Y, Chen YM (2017) Coupling of plant and soil C: N: P stoichiometry in black locust (Robinia pseudoacacia) plantations on the Loess Plateau, China. Trees 31: 1559-1570.

Carreira JA, Vinegla B, Laytha K (2006) Secondary $\mathrm{CaCO}_{3}$ and precipitation of P-Ca compounds control the retention of soil P in arid ecosystems. J Arid Environ 64: 460-473.

Chen SP, Wang WT, Xu WT, Wang Y, Wan HW, Chen DM, Tang ZY, Tang XL, Zhou GY, Xie ZQ, Zhou DW, Shangguan ZP, Huang JH, He JS, Wang YF, Sheng JD, Tang LS, Li XR, Dong M, Wu Y, Wang QF, Wu JG, Chapin FS, Bai YF (2018) Plant diversity enhances productivity and soil carbon storage. PNAS 115: 4027-4032.

Collins CG, Wright SJ, Wurzburger N (2016) Root and leaf traits reflect distinct resource acquisition strategies in tropical lianas and trees. Oecologia 180: 1037-1047.

Du YX, Pan GX, Li LQ, Hu ZL, Wang XZ (2011) Leaf N: P ratio and nutrient reuse between dominant species and stands: predicting phosphorus deficiencies in Karst ecosystems, Southwestern China. Environ Earth Sci 64: 299-309.

Du BM, Ji HW, Peng C, Liu XJ, Liu CJ (2016) Altitudinal patterns of leaf stoichiometry and nutrient resorption in Quercus variabilis in the Baotianman Mountains, China. Plant and Soil 413: 193-202.

Elser JJ, Sterner RW, Gorokhova E, Fagan WF, Markow TA, Cotner JB, Harrison JF, Hobbie SE, Odell GM, Weider LW (2008) Biological stoichiometry from genes to ecosystems. Ecology Letters 3: 540-550.

Elser JJ, Fagan WF, Kerkhoff AJ, Swenson NG (2010) Biological stoichiometry of plant production: metabolism, scaling and ecological response to global change. New Phytol 186: 593-608. 
Fan HB, Wu JP, Liu WF, Yuan YH, Hu L, Cai QK (2015) Linkages of plant and soil C: N: P stoichiometry and their relationships to forest growth in subtropical plantations. Plant and Soil 392: 127-138.

Gorokhova E, Kyle M (2002) Analysis of nucleic acids in daphnia: development of methods and ontogenetic variations in RNA-DNA content. J Plankton Res 24: 511-522.

Gusewell S (2005) Nutrient resorption of wetland graminoids is related to the type of nutrient limitation. Funct Ecol 19: 344-354.

Han WX, Fang JY, Guo DL, Zhang Y (2005) Leaf nitrogen and phosphorus stoichiometry across 753 terrestrial plant species in China. New Phytol 168: 377-385.

Hagedorn F, Mulder J, Jandl R (2010) Mountain soils under a changing climate and land-use. Biogeochemistry 97: 1-5.

Hong JT, Wu JB, Wang XD (2014) Root C: N: P stoichiometry of Stipa purpurea in Apine steppe on the northern Tibet. Mountain Research 32: 467-474.

Houlton BZ, Wang YP, Vitousek PM, Field CB (2008) A unifying framework for dinitrogen fixation in the terrestrial biosphere. Nature 454: 327-330.

Huang D, Wang DM, Ren Y (2019) Using leaf nutrient stoichiometry as an indicator of flood tolerance and eutrophication in the riparian zone of the Lijang River. Ecological Indicators 98: 821-829.

Jeyasingh PD, Weider LJ, Sterner RW (2009) Genetically-based trade-offs in response to stoichiometric food quality influence competition in a keystone aquatic herbivore. Ecology Letters 12: 1229-1237.

Jiang ZC, Lian Y, Qin X (2014) Rocky desertification in Southwest China Impacts, causes, and restoration. Earth Sci 132: 1-12.

Kirkby CA, Kirkegaard JA, Richardson AE, Wade LJ, Blanchard C, Batten G (2011) Stable soil organic matter: a comparison of C: N: P: S ratios in Australian and other world soils. Geoderma 163: 197-208.

Killingbeck KT (1996) Nutrients in senesced leaves: keys to the search for potential resorption and resorption proficiency. Ecology 77: 1716-1727.

Kobe R K, Lepczyk C A, lyer M (2005) Resorption efficiency decrease with increasing green leaf nutrients in a global data set. Ecology 86: 2780-2792.

Koerselman W, Meuleman AFM (1996) The vegetation N: P ratio: a new tool to detect the Nature of Nutrient Limitation. Journal of Applied Ecology 33: 1441-1450.

Leonardus V, Stefano M, Amilcare P, Roberto FN, Robert BJ (2012) Global resorption efficiencies and concentrations of carbon and nutrients in leaves of terrestrial plants. Ecological Monographs 82: 205220. 
Li DJ, Wen L, Zhang W, Yang LQ, Xiao KC, Chen H, Wang KL (2017) Afforestation effects on soil organic carbon and nitrogen pools modulated by lithology. Forest Ecology and Management 400: 85-92.

Li L, Zerbe S, Han W, Thevs N, Li W, He P, Schmitt AO, Liu Y, Ji C (2014) Nitrogen and phosphorus stoichiometry of common reed (Phragmites australis) and its relationship to nutrient availability in northern China. Aquat Bot 112: 84-90.

Li Y, Wu JS, Liu SL, Shen JL, Huang DY, Su YR, Wei WX, Syers JK (2012) Is the C: N: P stoichiometry in soil and soil microbial biomass related to the landscape and land use in southern subtropical China? Global Biogeochemical Cycle 26: GB4002.

Li YF, Li QY, Guo DY, Liang S, Wang YJ (2016) Ecological stoichiometry homeostasis of Leymus chinensis in degraded grassland in western Jilin Province, NE China. Ecol Eng 90: 387-391.

Liu JT, Gu ZJ, Shao HB, Zhou F, Peng SY (2016) N-P stoichiometry in soil and leaves of Pinus massoniana forest at different stand ages in the subtropical soil erosion area of China. Environ Earth Sci 75: 1091.

Luo YZ, Zeng T, Dong W, He YL, Xu SM (2013) Research of ecological stoichiometry of plant community in alpine Kobresia meadow. Chinese Journal of Grassland 35: 92-96.

Luo XZ, Hou EQ, Chen JQ, Li J, Zhang LL, Zang XW, Wen DZ (2020) Dynamics of carbon, nitrogen, and phosphorus stocks and stoichiometry resulting from conversion of primary broadleaf forest to plantation and secondary forest in subtropical China. Catena http://doi.org/10.1016/j.catena.

Ma B, Zhou ZY, Zhang CP, Zhang G, Hu YJ (2009) Inorganic phosphorus fractions in the rhizosphere of xerophytic shrubs in the Alxa Desert. J Arid Environ 73: 55-61.

Mayor JR, Wright SJ, Turner BL (2014) Species-specific responses of foliar nutrients to long term nitrogen and phosphorus additions in a lowland tropical forest. $\mathrm{J}$ Ecol 102: 36-44.

Mclntosh AC, Macdonald SE, Quideau SA (2016) Understory plant community composition is associated with fine-scale above-and below-ground resource heterogeneity in mature lodgepole pine (Pinus contorta) Forests. PLoS One 11: e0151436.

Mu CC, Zhang TJ, Zhang XK, Cao B, Peng XQ, Cao L, Su H (2016) Pedogenesis and physicochemical parameters influencing soil carbon and nitrogen of alpine meadows in permafrost regions in the northeastern Qinghai-Tibetan Plateau. Catena 141: 85-91.

Orefice J, Smith RG, Carroll J, Asbjornsen H, Kelting D (2017) Soil and understory plant dynamics during conversion of forest to silvopasture, open pasture, and woodlot. Agrofor Syst 91: 729-739.

Ostrowska A, Porebska G (2015) Assessment of the C: $\mathrm{N}$ ratio as an indicator of the decomposability of organic matter in forest soils. Ecol Indic 49: 104-109. 
Pan FJ, Zhang W, Liu SJ, Li DJ, Wang KL (2015) Leaf N: P stoichiometry across plant functional groups in the karst region of southwestern China. Trees 29: 883-892.

Pang DB, Cao JH, Dan XQ, Guan YH, Peng XW, Cui M, Wu XQ, Zhou JX (2018a) Recovery approach affects soil quality in fragile karst ecosystems of southwest China: Implications for vegetation restoration. Ecological Engineering 123: 151-160.

Pang DB, Wang GZ, Li GJ, Sun YL, Liu YG, Zhou JX (2018b) Ecological Stoichiometric Characteristics of Two Typical Plantations in the Karst Ecosystem of Southwestern China. Forests 9: 56.

Pang DB, Cui M, Liu YG, Wang GZ, Cao JH, Wang XR, Zhou JX (2019) Responses of soil labile organic carbon fractions and stocks to different vegetation restoration strategies. Ecological Engineering 138: 391-402.

Qiu XC, Wang HB, Peng DL, Liu X, Yang F, Li Z, Cheng S (2020) Thinning drives C: N: P stoichiometry and nutrient resorption in Larix principis-rupprechtii plantations in North China. Forest Ecology and Management http://doi.org/10.1016/j.foreco.2020.117984.

Reich PB, Oleksyn J (2004) Global patterns of plant leaf N and P in relation to temperature and latitude. Proc Natl Acad Sci 101: 11001-11006.

Rong Q, Liu J, Cai Y, Lu Z, Zhao Z, Yue W, Xia J (2015) Leaf carbon, nitrogen and phosphous stoichiometry of Tamarix chinensis Lour. in the Laizhou Bay coastal wetland, China. Ecol Eng 76: 57-65.

Shipley B, Lechowicz MJ, Wright I, Reich PB (2006) Fundamental trade-offs generating the worldwide leaf economics spectrum. Ecology 87: 535-541.

Sohrt J, Herschbach C, Weiler M (2018) Foliar P- but not N resorption efficiency depends on the Pconcentration and the N:P ratio in trees of temperate forests. Trees 32: 1443-1455.

Sun ZZ, Liu LL, Peng SS, Penuelas J, Zeng H, Piao SL (2016) Agerelated modulation of the nitrogen resorption efficiency response to growth requirements and soil nitrogen availability in a temperate pine plantation. Ecosystems 19: 698-709.

Tang L, Han W, Chen Y, Fang J (2013) Resorption proficiency and efficiency of leaf nutrients in woody plants in eastern China. J Plant Ecol 6: 408-417.

Tong R, Zhou BZ, Jiang LN, Ge XG, Cao YH (2020) The growth of Chinese fir is limited by nitrogen: Evidences from N: P ratio, $\mathrm{N}$ or $\mathrm{P}$ variability and NuRE based on a regional investigation. Forest Ecology and Management http://doi.org/10.1016/j.foreco.2020.117905.

Vergutz L, Manzoni S, Porporato A, Novais RF, Jackson RB (2012) Global resorption efficiencies and concentrations of carbon and nutrients in leaves of terrestrial plants. Ecol Monogr 82: 205-220. 
Vitousek PM, Porder S, Houlton BZ, Chadwick OA (2010) Terrestrial phosphorus limitation: mechanisms, implications, and nitrogen phosphorus interactions. Ecol Appl 20: 5-15.

Wang S, Yu G (2008) Ecological stoichiometry characteristics of ecosystem carbon, nitrogen and phosphorus elements. Acta Ecol Sin 28: 3937-3947.

Wang WQ, Sardans J, Wang C, Zeng CS, Tong C, Asensio D, Penuelas J (2015) Ecological stoichiometry of $\mathrm{C}, \mathrm{N}$, and $\mathrm{P}$ of invasive Phragmites australis and native Cyperus malaccensis species in the Minjiang River tidal estuarine wetlands of China. Plant Ecology 216: 809-822.

Wang MM, Chen HS, Zhang W, Wang KL (2018) Soil nutrients and stoichiometric ratios as affected by land use and lithology at county scale in a karst area, southwest China. Sci Total Environ 619: 12991307.

Wang FC, Fang XM, Wang GG, Mao R, Lin XF, Wang HM, Chen FS (2019) Effects of nutrient addition on foliar phosphorus fractions and their resorption in different-aged leaves of Chinese fir in subtropical China. Plant and Soil 443: 41-54.

Wright I J, Cannon K (2001) Relationships between leaf lifespan and structural defences in a low-nutrient, sclerophyll flora. Functional Ecology 15: 351-359.

Wu TG, Wang GG, Wu QT, Cheng XR, Yu MK, Wang W, Yu XB (2014) Patterns of leaf nitrogen and phosphorus stoichiometry among Quercus acutissima provenances across China. Ecological Complexity 17: 32-39.

Yan ER, Wang XH, Zhou W (2008) N: P stoichiometry in secondary succession in evergreen broad-leaved forest, Tiantong, east China. J Plant Ecol 32: 13-22 (in Chinese).

Yan E, Wang X, Huang J (2006) Shifts in plant nutrient use strategies under secondary forest succession. Plant and Soil 289: 187-197.

Yan ZB, Namyoung K, Han WX, Guo YL, Han TS, Du EZ, Fang JY (2015) Effects of nitrogen and phosphorus supply on growth rate, leaf stoichiometry, and nutrient resorption of Arabidopsis thaliana. Plant and Soil 388: 147-155.

Yang Y, Liu BR, An SS (2018) Ecological stoichiometry in leaves, roots, litters and soil among different plant communities in a desertified region of Northern China. Catena 166: 328-338.

You CM, Wu FZ, Yang WQ, Xu ZF, Tan B, Zhang L, Yue K, Ni XY, Li H, Chang CH, Fu CK (2018) Does foliar nutrient resorption regulate the coupled relationship between nitrogen and phosphorus in plant leaves in response to nitrogen deposition? Science of the Total Environment 645: 733-742.

Yu Q, Elser J, He N, Wu H, Chen Q, Zhang G, Han X (2011) Stoichiometric homeostasis of vascular plants in the Inner Mongolia grassland. Oecologia 166: 1-10. 
Yuan Z, Chen HY (2009) Global-scale patterns of nutrient resorption associated with latitude, temperature and precipitation. Global Ecol Biogeog 18: 11-18.

Yuan ZY, Chen HY (2015) Negative effects of fertilization on plant nutrient resorption. Ecology 96 : $373-$ 380.

Zeng YL, Fang X, Xiang WH, Deng XW, Peng CH (2017) Stoichiometric and nutrient resorption characteristics of dominant tree species in subtropical Chinese forests. Ecology and Evolution http:// doi: 10.1002/ece3.3527.

Zhang W, Liu W, Xu M, Deng J, Han X, Yang G, Feng Y, Ren G (2019) Response of forest growth to C: N: P stoichiometry in plants and soils during Robinia pseudoacacia afforestation on the Loess Plateau, China. Geoderma 337: 280-289.

Zhang H, Wang J, Wang J, Guo Z, Wang GG, Zeng D, Wu T (2018) Tree stoichiometry and nutrient resorption along a chronosequence of Metasequoia glyptostroboides forests in coastal China. Forest Ecol Manag 430: 445-450.

Zhang SB, Zhang JL, Slik J, Cao KF (2012) Leaf element concentrations of terrestrial plants across China are influenced by taxonomy and the environment. Global Ecol Biogeog 21: 809-818.

Zhao XL, He XD, Xue PP, Zhang N, Wu W, Li R, Ci HC, Xu JJ, Gao YB, Zhao HL (2012) Effects of soil stoichiometry of the $\mathrm{CaCO}_{3}$ /available phosphorus ratio on plant density in Artemisia ordosica communities. Chinese Science Bulletin 57: 492-499.

Zhao F, Sun J, Ren C, Kang D, Deng J, Han X, Yang G, Feng Y, Ren G (2015) Land use change influences soil C, N and P stoichiometry under 'Grain-to-Green Program' in China. Sci Rep 5: http://10.1038/srep10195.

Zhou L, Addo-Danso SD, Wu P, Li S, Zou X, Zhang Y, Ma X (2016) Leaf resorption efficiency in relation to foliar and soil nutrient concentrations and stoichiometry of Cunninghamia lanceolata with stand development in southern China. Journal of Soil and Sediments 16: 1448-1459.

Zhu HH, He XY, Wang KL, Su YR, Wu JS (2012) Interaction of vegetation succession, soil biochemical properties and microbial communities in Karst ecosystem. European Journal of Soil Biology 51: 1-7.

\section{Figures}




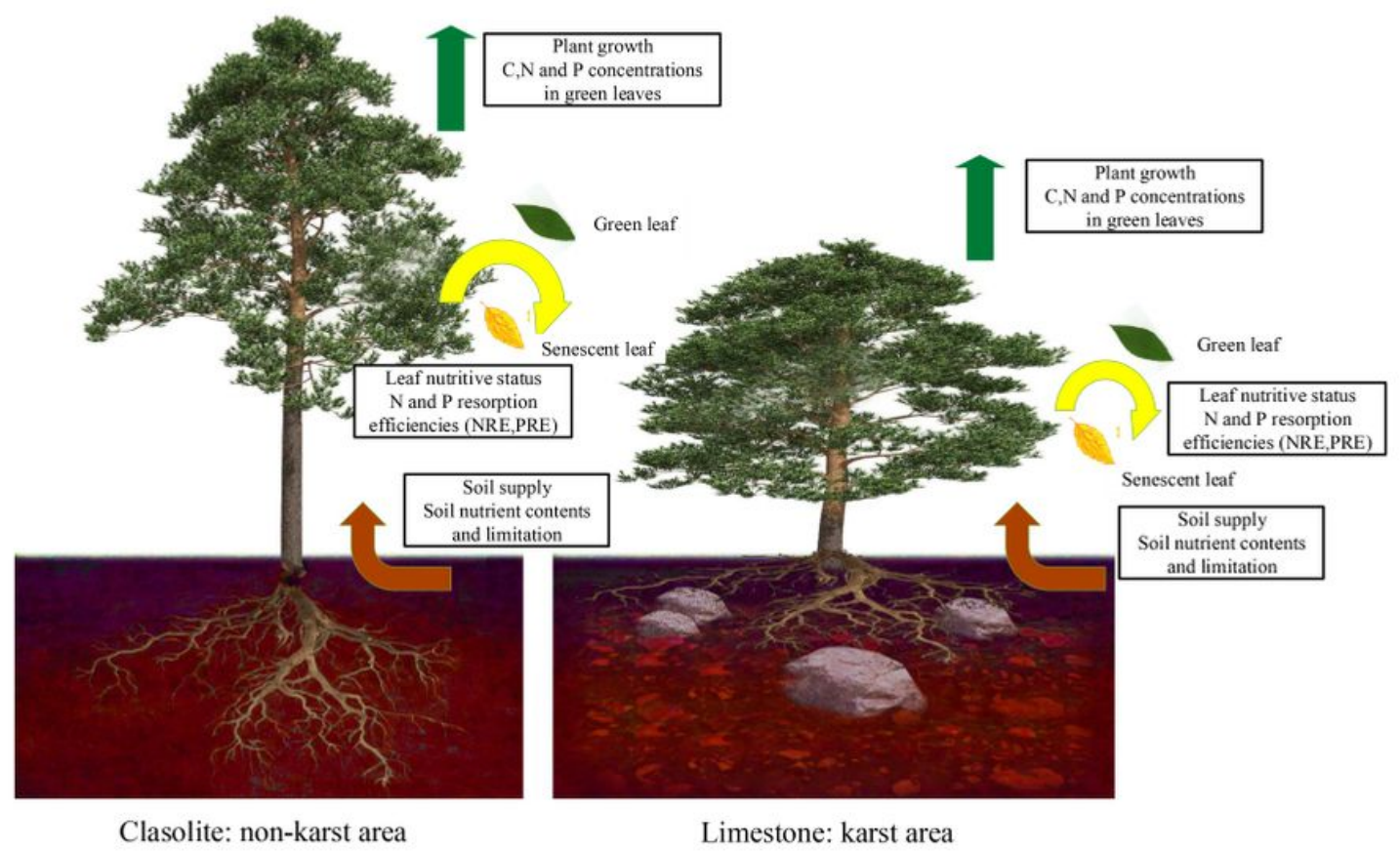

Figure 1

Morphological, nutrient limitation, and resorption efficiency difference between the two stands growing on different soil types. 

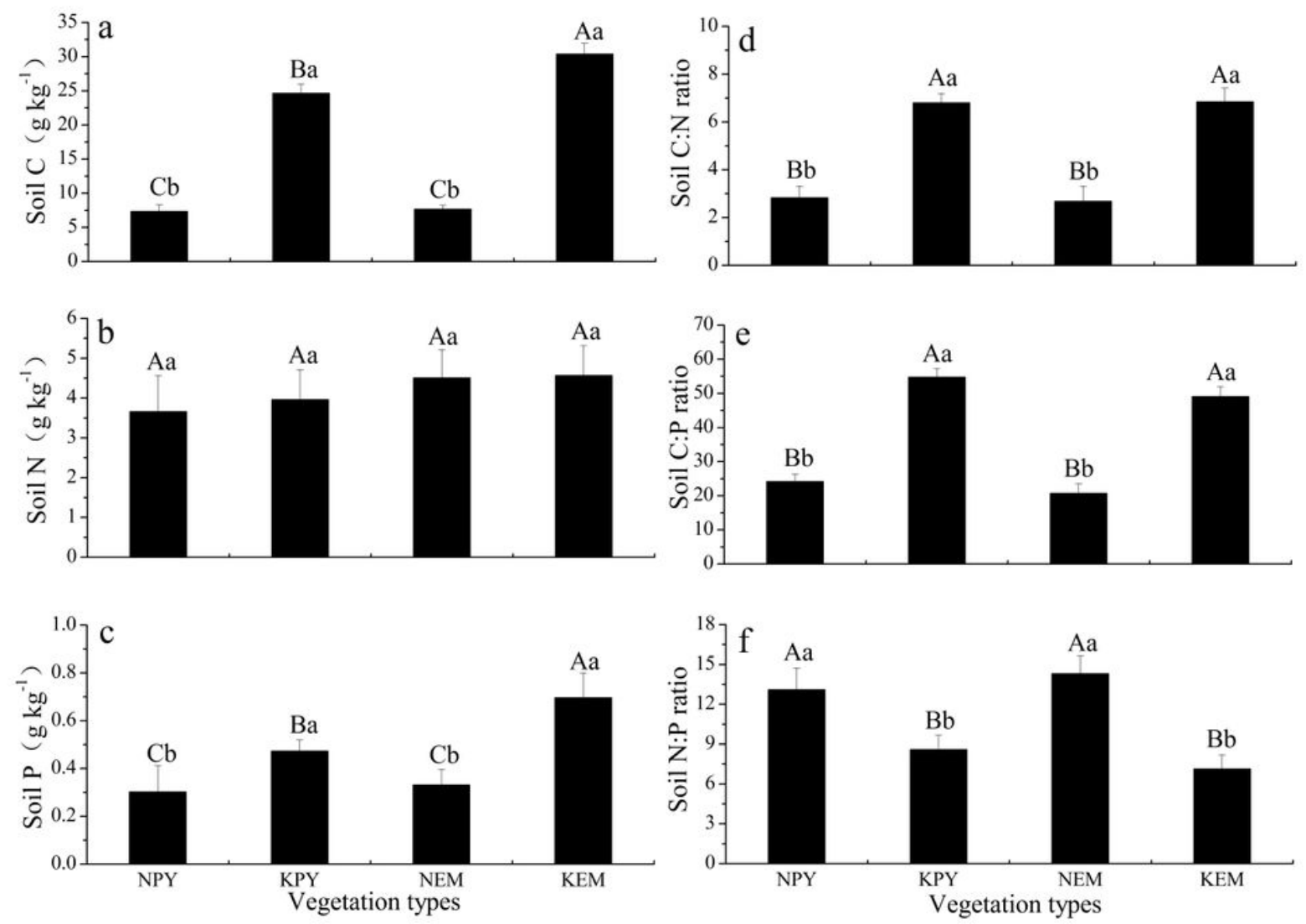

Figure 2

The stoichiometric characteristics of soil C, N, and P. (a) C concentration, (b) N concentration, (c) P concentration, (d) C:N ratio, (e) C:P ratio, and (f) N:P ratio. NPY: non-karst Pinus yunnanensis Franch. (PY); KPY: karst Pinus yunnanensis Franch. (PY) ; NEM: non-karst Eucalyptus maideni F. Muell. (EM); KEM: karst Eucalyptus maideni F. Muell. (EM). The capital letter denotes a significant difference between

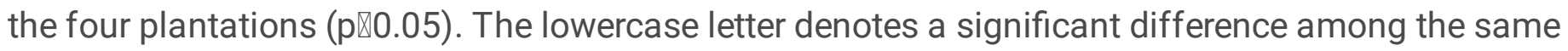
plantation in different areas ( $\mathrm{p} \otimes 0.05)$. Error bars represent standard error. 

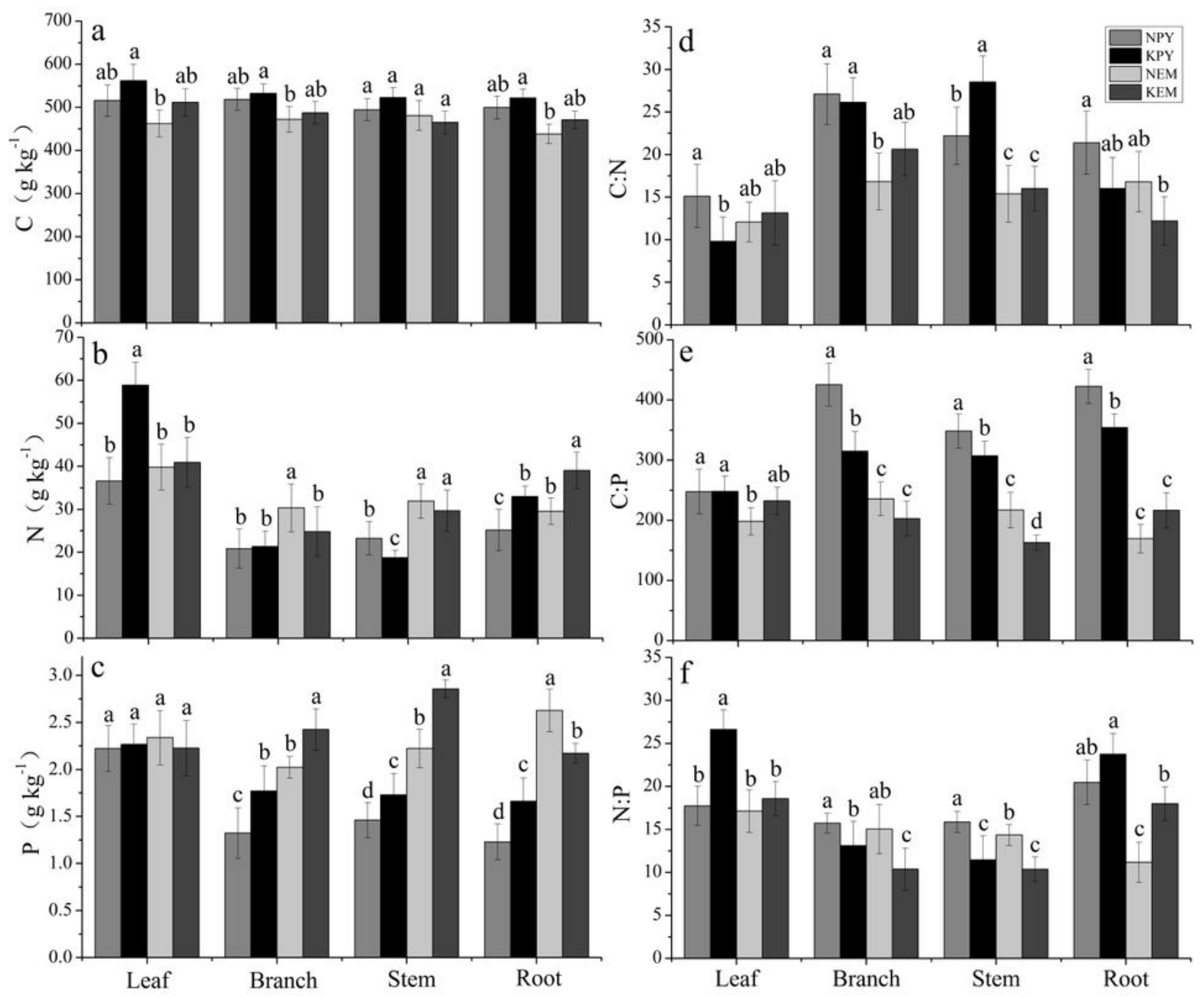

Figure 3

The stoichiometric characteristics of $\mathrm{C}, \mathrm{N}$, and $\mathrm{P}$ measured in different plant organs. (a) C concentration, (b) N concentration, (c) P concentration, (d) C:N ratio, (e) C:P ratio, and (f) N:P ratio. The lowercase letter denotes a significant difference among each plant organ ( $\mathrm{p} \otimes 0.05)$. Error bars represent standard error. 

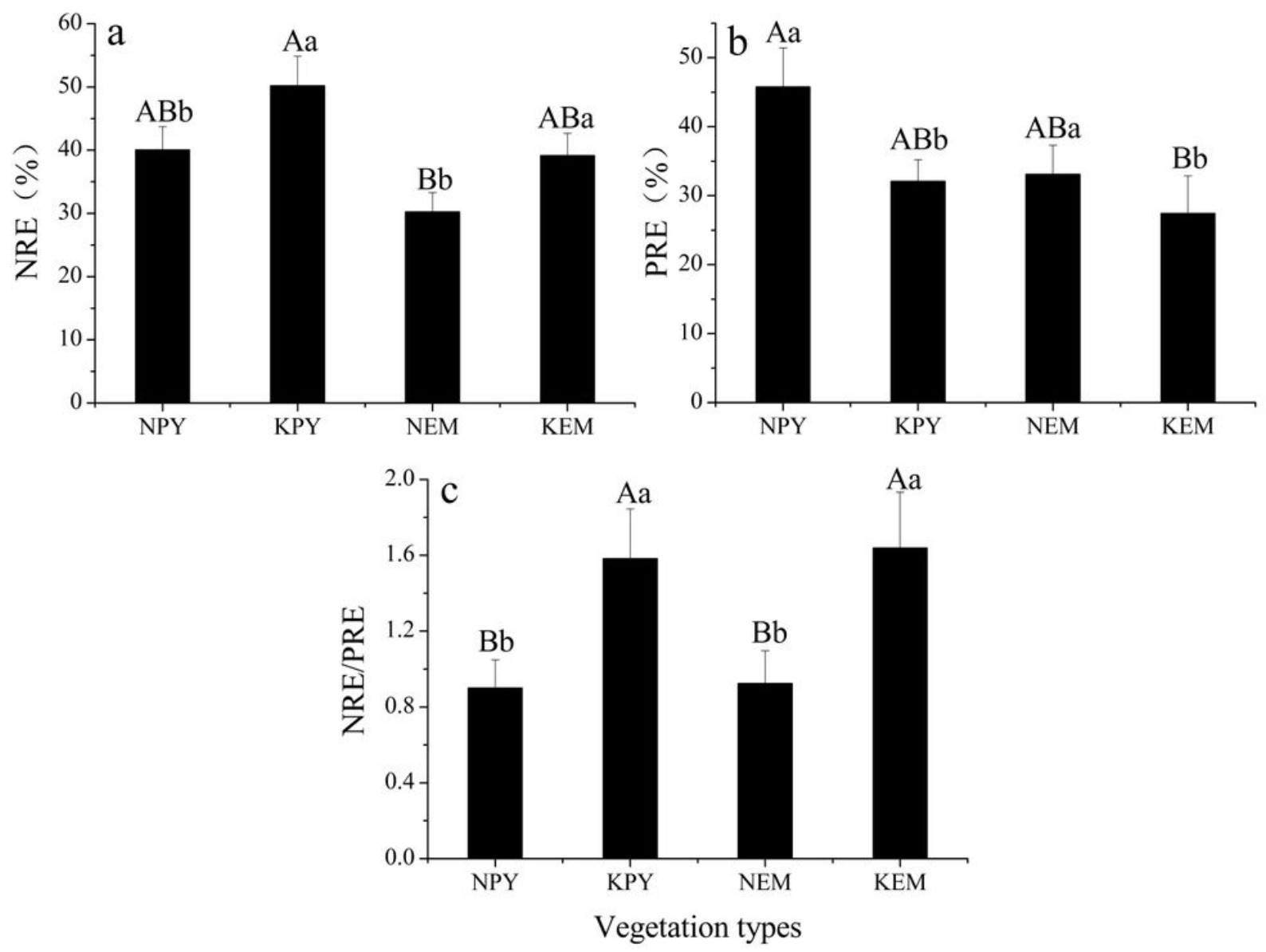

Figure 4

Changes in NRE (a), PRE (b) and NRE: PRE (c) among different plantations. The capital letter denotes a significant difference between the four plantations ( $p \otimes 0.05$ ), and the lowercase letter denotes a significant difference among the same plantation in different areas ( $\mathrm{p} \otimes 0.05)$. Error bars represent standard error. 

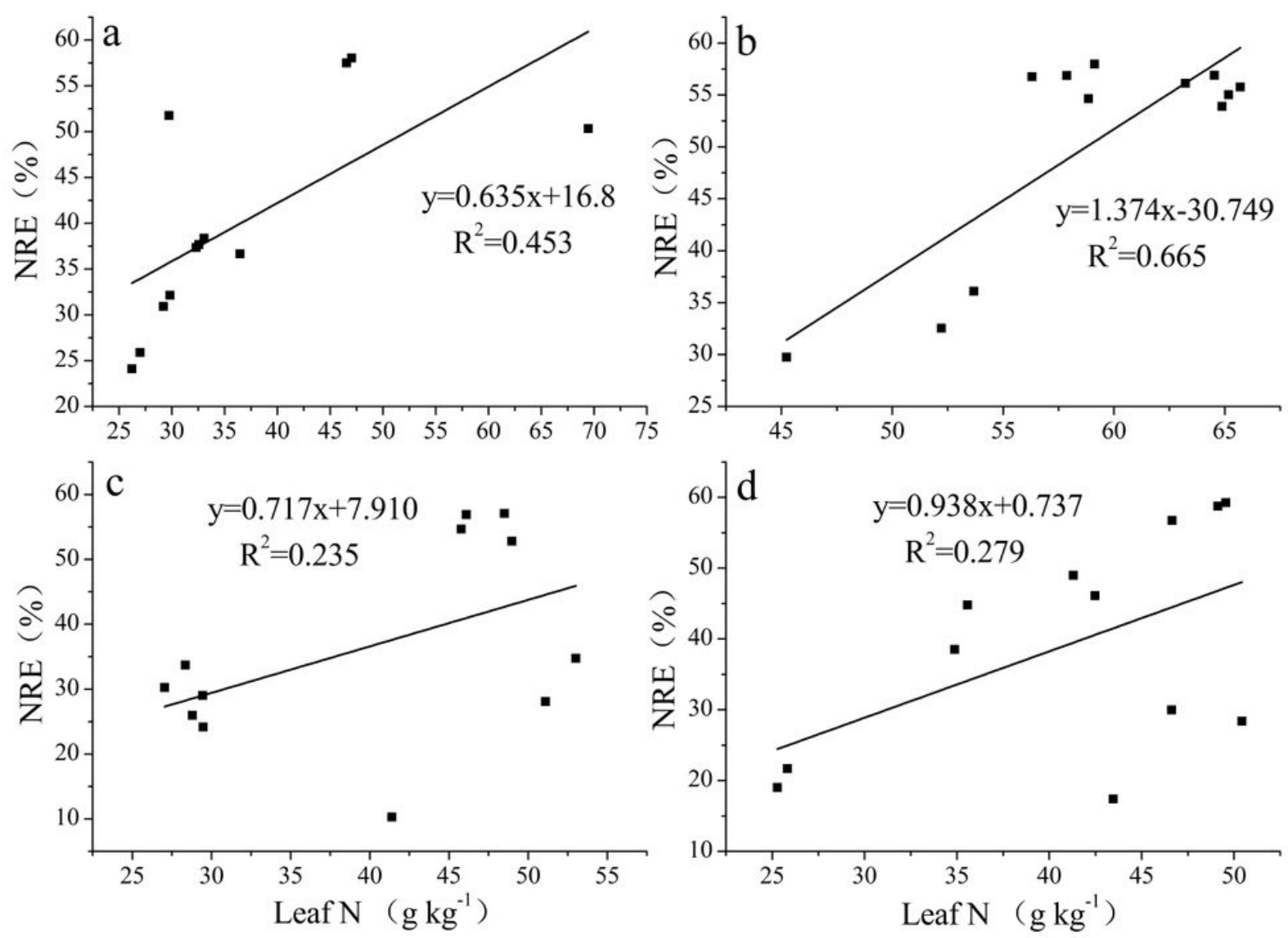

Figure 5

Relationships between NRE and leaf N concentrations. (a) Pinus yunnanensis Franch. (PY) in the nonkarst area, (b) Pinus yunnanensis Franch. (PY) in the karst area, (c) Eucalyptus maideni F. Muell. (EM) in the non-karst area, (d) Eucalyptus maideni F. Muell. (EM) in the karst area. The same abbreviations are used in subsequent figures. 

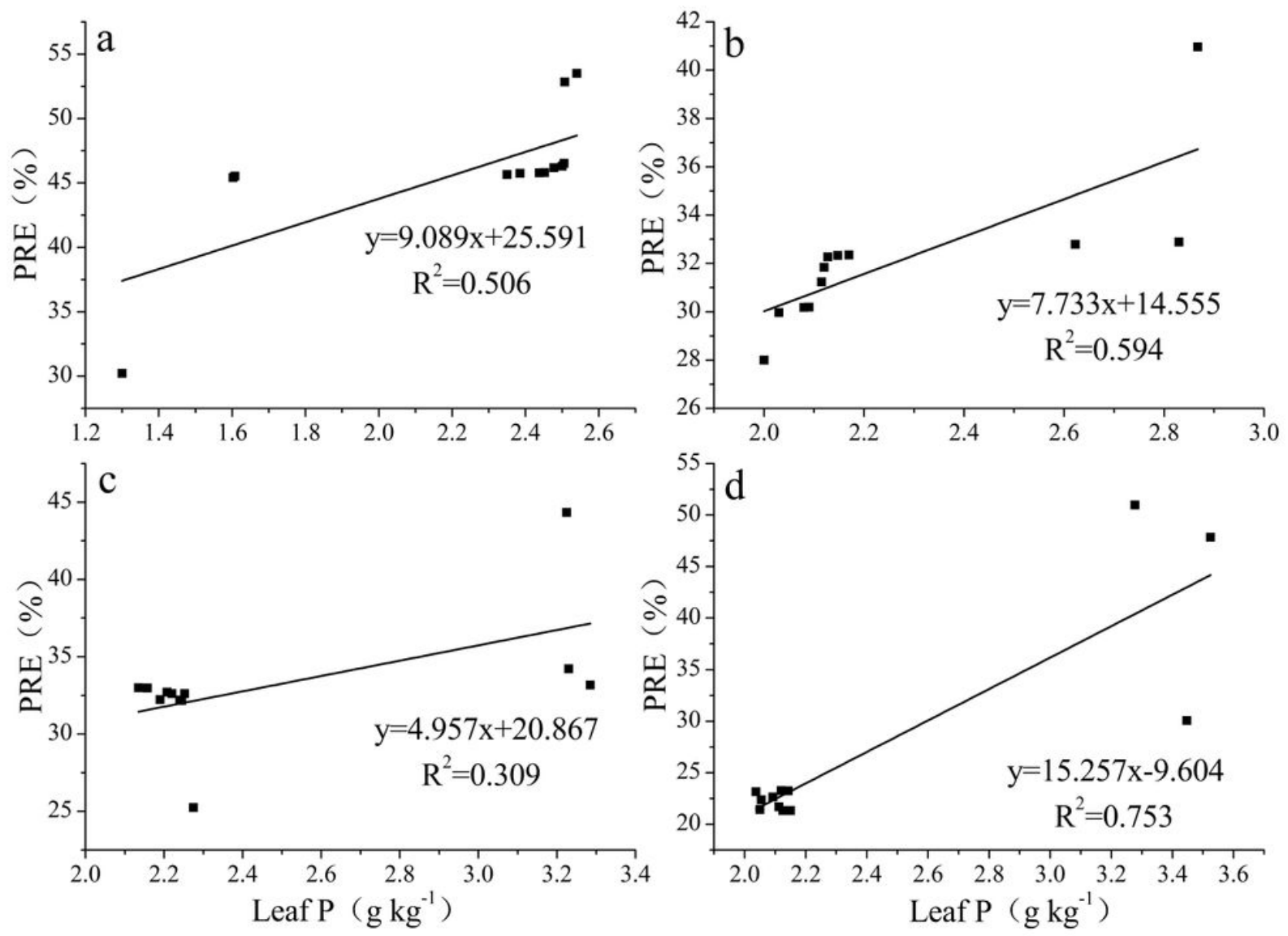

Figure 6

Relationships between NRE and leaf N: P ratio. 

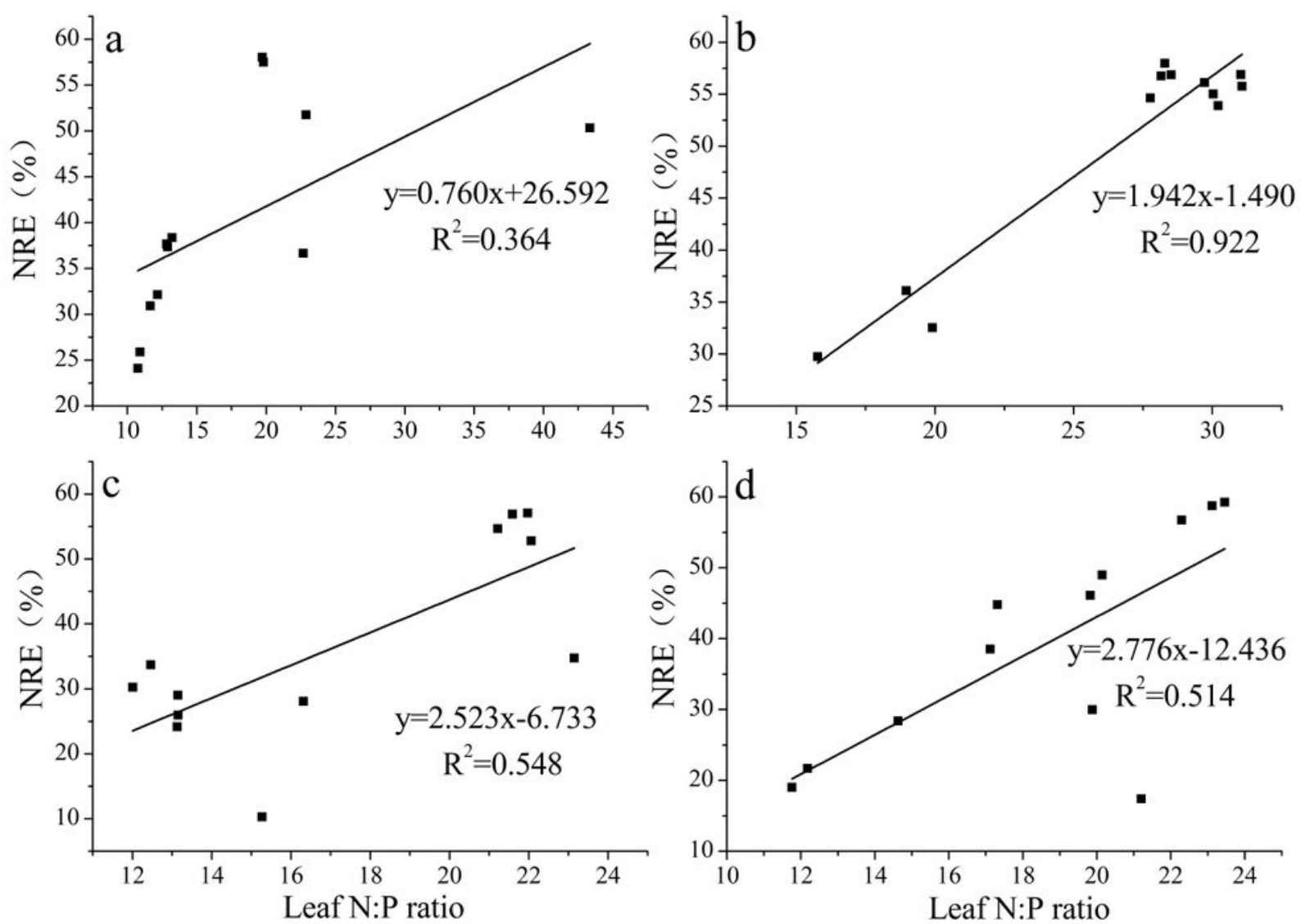

Figure 7

Relationships between PRE and leaf P concentrations. 

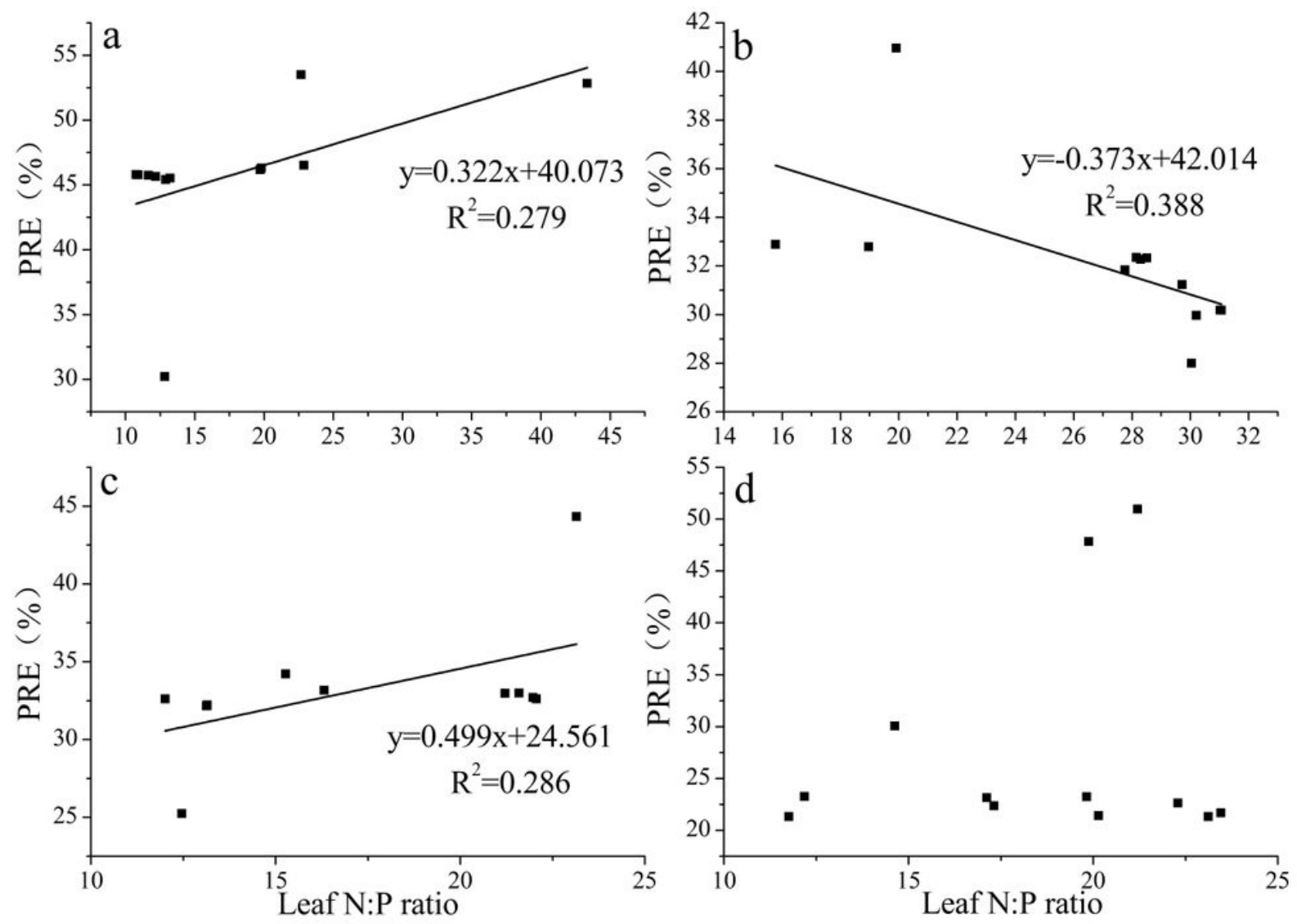

Figure 8

Relationships between PRE and leaf N: P ratio.

\section{Supplementary Files}

This is a list of supplementary files associated with this preprint. Click to download.

- equation.docx 